\title{
Milk osteopontin retains integrin-binding activity after in vitro gastrointestinal transit
}

\author{
B. Christensen, ${ }^{1,2}$ N. J. Karlsen, ${ }^{1}$ S. D. S. Jørgensen, ${ }^{3}$ L. N. Jacobsen, ${ }^{4}$ M. S. Ostenfeld, ${ }^{4}$ S. V. Petersen, ${ }^{5} \odot$ \\ A. Müllertz, ${ }^{3}$ and E. S. Sørensen ${ }^{1,2 *}$ (i) \\ ${ }^{1}$ Department of Molecular Biology and Genetics, Aarhus University, DK-8000 Aarhus, Denmark \\ ${ }_{2} \mathrm{iFood}$, Aarhus University Center for Innovative Food Research, DK-8000 Aarhus, Denmark \\ ${ }^{3}$ Department of Pharmacy, Faculty of Health and Medical Sciences, University of Copenhagen, DK-2100 Copenhagen, Denmark \\ ${ }^{4}$ Arla Foods Ingredients Group P/S, DK-8260 Viby J, Denmark \\ ${ }^{5}$ Department of Biomedicine, Aarhus University, DK-8000 Aarhus, Denmark
}

\begin{abstract}
Osteopontin $(\mathrm{OPN})$ is a multifunctional protein highly expressed in milk, where it is hypothesized to be involved in immunological signaling via the conserved Arg-Gly-Asp (RGD) integrin-binding sequence. Intervention studies have indicated beneficial effects of orally administered OPN in animal and human infants, but the mechanisms underlying these effects are not well described. To induce physiological effects, OPN must resist gastrointestinal transit in a bioactive form. In this study, we subjected bovine milk OPN to in vitro gastrointestinal transit, and characterized the generated fragments using monoclonal antibody and mass spectrometric analyses. We found that the fragment $\operatorname{Trp}^{27}$-Phe ${ }^{151}$ containing the integrin-binding RGD sequence resisted in vitro gastric digestion. This resistance was dependent on glycosylation of threonine residues near the integrin-binding sequence in both human and bovine milk OPN. Furthermore, the fragment $\operatorname{Trp}^{27}-\mathrm{Phe}^{151}$ retained the ability to interact with integrins in an RGD-dependent process. These results suggest a mechanism for how ingested milk OPN can induce physiological effects via integrin signaling in the intestine.
\end{abstract}

Key words: osteopontin, bioactive milk proteins, gastrointestinal digestion, infant formula

\section{INTRODUCTION}

Osteopontin (OPN) is a multifunctional protein present in most tissues and body fluids, and its highest

Received July 5, 2019.

Accepted September 30, 2019.

*Corresponding author: ess@mbg.au.dk concentrations are found in milk. It contains the wellknown integrin-binding sequence Arg-Gly-Asp (RGD), which mediates binding to many different integrins, including the most important receptor, the $\alpha_{\mathrm{V}} \beta_{3}$-integrin. The OPN integrin interactions initiate and regulate many of the functions propagated by the protein, such as cell adhesion, migration, bone resorption, and immune modulation (Christensen et al., 2012; Kahles et al., 2014; Park et al., 2016; Lok and Lyle, 2019). In addition, OPN contains a second cryptic integrin-binding motif, the SVVYGLR sequence (SVAYGLK in bovine OPN), located next to the RGD sequence (Yokosaki et al., 2005; Christensen et al., 2010).

Osteopontin is extensively altered through posttranslational modification such as phosphorylation, glycosylation, and proteolytic processing. These modifications have significant implications for the functionality of the protein and its interactions with integrins (Lok and Lyle, 2019). The region containing the 2 integrin-binding motifs also contains several $O$ glycosylated threonine residues (Sørensen et al., 1995). These threonines are well conserved among mammalian OPN sequences, but no clear functional role for the glycosylations has been described. In human and bovine milk, OPN is present as both an intact full-length protein and as several proteolytically generated $\mathrm{N}$-terminal fragments (Christensen et al., 2010; Christensen and Sørensen, 2014). The N-terminal fragments are generated by proteolytic cleavage in the sequence to the Cterminal side of the RGD and SVVYGLR sequences.

The average levels of OPN in milk from Danish mothers have been determined to be 99.7 to $138 \mathrm{mg} / \mathrm{L}$ (Schack et al., 2009; Bruun et al., 2018), whereas average levels in milk from Asian mothers were significantly higher, at 185.0 to $266.2 \mathrm{mg} / \mathrm{L}$ (Bruun et al., 2018). In bovine milk, average OPN levels are significantly lower, at $18 \mathrm{mg} / \mathrm{L}$ (Schack et al., 2009). In comparison, the levels of OPN in plasma and urine have been reported 
to be approximately $35 \mu \mathrm{g} / \mathrm{L}$ and $4 \mathrm{mg} / \mathrm{L}$, respectively (Schack et al., 2009; Kolbach et al., 2012). The biological role of OPN in milk is not clear, but several functions have been suggested. For instance, OPN is a very acidic protein that can form soluble complexes with calcium ions, which could inhibit precipitation of amorphous calcium phosphate in milk (Holt et al., 2014). As well, OPN has been shown to induce expression of the T-helper (Th)1 cytokine IL-12 and inhibit production of the Th2 cytokine IL-10 (Ashkar et al., 2000). Therefore, OPN could play a role in modulating the developing immune system of infants. Furthermore, ingested milk OPN may play a role at the gut mucosal surface of infants, because OPN can induce the expression of interleukin-12 from intestinal mononuclear cells (Schack et al., 2009).

Animal and human intervention trials with infant formulas have shown that the addition of bovine milk OPN affects intestinal gene expression and affects immune function. In infant formula, OPN in a concentration comparable to that in human milk $(125 \mathrm{mg} / \mathrm{L})$ significantly shifted intestinal gene expression toward that of breastfed infant monkeys (Donovan et al., 2014). In a randomized, double-blind clinical trial, human infants were either breastfed or formula-fed with a standard formula or a formula containing bovine milk OPN in concentrations of 65 or $130 \mathrm{mg} / \mathrm{L}$ (Lönnerdal et al., 2016). The addition of OPN to the formula significantly lowered plasma levels of proinflammatory cytokines and increased levels of IL-2, which plays key roles in oral tolerance. Furthermore, infants who received the OPN formula had fewer days with fever than infants who received the standard formula. Supplementing infant formula with OPN has also been shown to increase the proportion of circulating T cells (West et al., 2017). Collectively, these studies indicate that orally administered OPN may pass through the stomach in a form that enables delivery of an immunological signal in the intestine of the infant. However, it is largely unknown whether the OPN species that resist digestion contain the RGD and SVVYGLR motifs that are important for interaction with integrins.

In this study, OPN from bovine milk was digested in vitro under conditions simulating proteolysis in the gastrointestinal tract with respect to $\mathrm{pH}$ and proteaseto-protein ratios, using pepsin (gastric digestion) and trypsin/chymotrypsin (intestinal digestion). We investigated the influence of the glycosylations on digestion by comparing the digestion of native OPN and deglycosylated OPN with specific antibodies and mass spectrometric analyses. We also investigated the ability of the digested OPN to interact with integrin receptors in cell adhesion studies.

\section{MATERIALS AND METHODS}

\section{Purification and Deglycosylation of Osteopontin}

Bovine milk OPN (Lacprodan OPN-10, Arla Foods Ingredients, Viby, Denmark) was stored at $-20^{\circ} \mathrm{C}$. For deglycosylation of $O$-linked glycans, the OPN was incubated with O-glycanase (Agilent Technologies Inc., Santa Clara, CA; $1.25 \mathrm{mU} / \mathrm{mg}$ of OPN) and sialidase-A (Agilent Technologies Inc.; $5 \mathrm{mU} / \mathrm{mg}$ of OPN) in reaction buffers provided by the manufacturer at $37^{\circ} \mathrm{C}$ for $16 \mathrm{~h}$. The deglycosylated OPN was dialyzed against 10 $\mathrm{m} M$ ammonium bicarbonate buffer, followed by lyophilization. Human OPN from breast milk was purified by anion-exchange chromatography on DEAE-Sepharose CL-6B (GE Healthcare, Uppsala, Sweden) and barium chloride and sodium citrate precipitation as described by Christensen et al. (2010). Recombinant OPN was expressed in Escherichia coli BL21cc and purified as described by Christensen et al. (2016).

\section{In Vitro Digestion of Osteopontin}

The OPN (native glycosylated and deglycosylated) was dissolved in $0.15 \mathrm{M} \mathrm{NaCl}, \mathrm{pH} 2.5$, to a concentration of $1 \mathrm{mg} / \mathrm{mL}$ and incubated with pepsin from porcine gastric mucosa (Sigma-Aldrich, St. Louis, MO) at an enzyme-to-substrate ratio of either 1:400 (wt/wt) or 1:50 (wt/wt) for $60 \mathrm{~min}$ at $37^{\circ} \mathrm{C}$. Before digestion with pancreatic proteases, the samples were evaporated and washed twice with deionized water. Digestion with trypsin and chymotrypsin (Worthington Biochemical Corporation, Lakewood, NJ; both from bovine pancreas) were performed at 1:400 (wt/wt) or 1:50 (wt/wt) enzyme-to-substrate ratios in $0.1 M$ ammonium bicarbonate buffer $(\mathrm{pH} 7)$ for $60 \mathrm{~min}$ at $37^{\circ} \mathrm{C}$. The proteases were then inactivated by adding phenylmethanesulfonyl fluoride (to $1.5 \mathrm{mM}$ ).

We used a combined gastric and intestinal in vitro digestion model simulating adult human gastrointestinal conditions as described by Thomas et al. (2014). Briefly, the model was composed of gastric and intestinal media (Table 1), which simulated human gastrointestinal conditions with respect to volumes of media, acidity, enzyme activity, and phospholipid and bile salt concentrations (Table 1). Five milligrams of OPN and $50 \mathrm{mg}$ of skim milk powder were dissolved in $15 \mathrm{~mL}$ of gastric medium (Table 1) in a thermo-jacketed reaction vessel (diameter $7 \mathrm{~cm}$, length $7.5 \mathrm{~cm}$ ) at $37^{\circ} \mathrm{C}$ and stirred for $30 \mathrm{~min}$. Samples were collected at 5, 15, and $30 \mathrm{~min}$. Then the intestinal medium was simulated by adding $10 \mathrm{~mL}$ of concentrated intestinal medium and $5 \mathrm{~mL}$ of pancreatin solution into the same vessel containing the 
Table 1. Composition of the fasted state digestion media as used for gastric and intestinal in vitro digestion

\begin{tabular}{lccccccc}
\hline Digestion & $\mathrm{pH}$ & $\begin{array}{c}\text { Pepsin } \\
(\mathrm{mg} / \mathrm{mL})\end{array}$ & $\begin{array}{c}\text { Pancreatin } \\
\left(\mathrm{USP}^{1} / \mathrm{mL}\right)\end{array}$ & $\begin{array}{c}\text { Bile salts } \\
(\mathrm{m} M)\end{array}$ & $\begin{array}{c}\text { Maleate } \\
(\mathrm{m} M)\end{array}$ & $\begin{array}{c}\text { NaCl } \\
(\mathrm{m} M)\end{array}$ & $\begin{array}{c}\text { Phospholipid } \\
(\mathrm{m} M)\end{array}$ \\
\hline Gastric & 2.0 & 0.15 & - & 0.08 & 2 & 34.2 & 0.02 \\
Intestinal & 6.5 & - & 550 & 3 & 2 & 50 & 0.26 \\
\hline
\end{tabular}

${ }^{1}$ USP $=$ United States Pharmacopeia units.

gastric medium, leading to the concentrations shown in Table 1. The intestinal digestion was carried out for 60 min at $37^{\circ} \mathrm{C}$, during which $\mathrm{pH}$ was maintained at 6.5 by titration with $0.4 \mathrm{M} \mathrm{NaOH}$. Samples were taken at $35,45,60$, and 90 min of digestion, and the enzyme activity was inhibited by adding phenylmethanesulfonyl fluoride (to $1.5 \mathrm{mM}$ ). Samples were analyzed for OPN content by Western blotting, described below.

\section{Antibodies and Western Blotting}

The monoclonal mouse antibody MAB222p raised against the DSVVYG sequence in human OPN was from Maine Biotechnology Services (Portland, ME); MAB222p was verified to recognize the homologous sequence in the N-terminal part of bovine OPN by Western blotting. Samples from the proteolytic digests were separated on 10\% NuPAGE Novex Bis-Tris precast gels (Invitrogen, Carlsbad, CA), followed by electroblotting onto Hybond-P PVDF membranes (GE Healthcare) for immunodetection. The membranes were blocked in $2 \%$ Tween in Tris-buffered saline before addition of MAB222p $(2.5 \mu \mathrm{g} / \mathrm{mL})$. The OPN was detected with horseradish peroxidase-conjugated secondary immunoglobulins with enhanced chemiluminescence on an ImageQuant LAS 4000 instrument (GE Healthcare).

\section{Separation of Peptides}

Digests were separated by reversed-phase HPLC on a Vydac C18 column (The Separations Group, Hesperia, CA) connected to a Shimadzu (Kyoto, Japan) HPLC system. The peptides were separated in $0.1 \%$ trifluoroacetic acid (buffer A) and eluted with a gradient of $60 \%$ acetonitrile in $0.1 \%$ trifluoroacetic acid (buffer $\mathrm{B})$. The gradient was developed over $59 \mathrm{~min}(0-5 \mathrm{~min}$, 0\% buffer B; 5-49 min, 98\% buffer B; 49-59 min, $98 \%$ buffer B) at a flow rate of $0.85 \mathrm{~mL} / \mathrm{min}$. Peptides and fragments were detected by measuring the absorbance at $226 \mathrm{~nm}$, and the resulting fractions were collected for analysis. In addition to the reversed-phase separation, parts of the digests were separated by gel filtration on a Superdex Peptide HR 10/30 column (GE Healthcare). The column was equilibrated with $0.1 \mathrm{M}$ ammonium bicarbonate, $\mathrm{pH}$ 8.1, and operated at a flow rate of
$0.3 \mathrm{~mL} / \mathrm{min}$. The collected fractions were analyzed by Western blotting using the MAB222p antibody.

\section{Mass Spectrometric Analyses}

Fifty-microliter aliquots of fractions from gel filtration of native and deglycosylated OPN digested by pepsin at an enzyme-to-substrate ratio of 1:50 (wt/wt) were lyophilized in a vacuum centrifuge, resuspended in $50 \mathrm{mM}$ ammonium bicarbonate, and digested with endoproteinase Asp-N or trypsin (both from Sigma-Aldrich) at $37^{\circ} \mathrm{C}$ for $18 \mathrm{~h}$ using $40 \mathrm{ng}$ of each protease. All samples were analyzed by MALDI-MS using a Bruker Autoflex III (Bruker Daltonics, Bremen, Germany). Tryptic and Asp-N peptides were analyzed using a saturated solution of $\alpha$-cyano-4-hydroxycinnamic acid (Sigma-Aldrich). The instrument was operated in reflector mode and calibrated in the mass range of 1,000 to 3,200 Da using the peptide calibration standard (Bruker Daltonics). We calculated theoretical peptide masses using the GPMAW program (Lighthouse Data, Odense, Denmark).

\section{Cell Adhesion Assays}

The human MDA-MB-435 cell line was maintained in Dulbecco's modified Eagle's medium with Glutamax (Invitrogen), supplemented with 10\% fetal bovine serum and $1 \%$ antibiotics (penicillin/streptomycin) at $37^{\circ} \mathrm{C}$ and $5 \% \mathrm{CO}_{2}$. Flat-bottomed 96-well tissueculture-treated polystyrene microtiter plates (Corning Inc., Corning, NY) were coated with fractions from the gel filtrations $(5 \mu \mathrm{g} / \mathrm{mL})$ in PBS at $4^{\circ} \mathrm{C}$ overnight, and then blocked with $1 \%$ BSA. The cells were trypsinized, washed twice, and resuspended to $5 \times 10^{5}$ cells $/ \mathrm{mL}$ in Dulbecco's modified Eagle's medium containing 1 $\mathrm{mg} / \mathrm{mL}$ bovine serum albumin. For blocking of integrin function, cells were pre-incubated with GRGDNP or GRADSP control peptide (Enzo Life Sciences, Lörrach, Germany) at $37^{\circ} \mathrm{C}$ for $30 \mathrm{~min}$. Then, cells $(100 \mu \mathrm{L})$ were added to coated wells and incubated for $2 \mathrm{~h}$ at $37^{\circ} \mathrm{C}$ in a humidified atmosphere with $5 \% \mathrm{CO}_{2}$. Nonadhered cells were removed by washing twice with $75 \mu \mathrm{L}$ of Percoll (Sigma-Aldrich; $73 \%$ Percoll, $0.9 \% \mathrm{NaCl}$ ), and adherent cells were fixed with $50 \mu \mathrm{L}$ of fixative $(10 \%$ glutar- 
aldehyde in Percoll). Fixed cells were stained with 100 $\mu \mathrm{L}$ of $0.5 \%$ toluidine blue and solubilized in $50 \mu \mathrm{L}$ of $0.5 \%$ Triton X-100 before reading at $630 \mathrm{~nm}$ using a microplate autoreader.

\section{RESULTS}

Bovine milk OPN was digested with pepsin and then with trypsin and chymotrypsin at different enzyme- to-substrate ratios to simulate gastrointestinal transit. The digests were analyzed by reversed-phase HPLC (Figure 1). Undigested OPN eluted at 31 to $36 \mathrm{~min}$, and we observed peaks with similar retention times after $60 \mathrm{~min}$ of incubation with pepsin at both enzymeto-substrate ratios (Figure $1 \mathrm{~A}-\mathrm{C}$ ). This suggests that large fragments of OPN were resistant to digestion with pepsin. After incubation for $1 \mathrm{~h}$ with pancreatic enzymes, the size of the peak eluting with similar re-
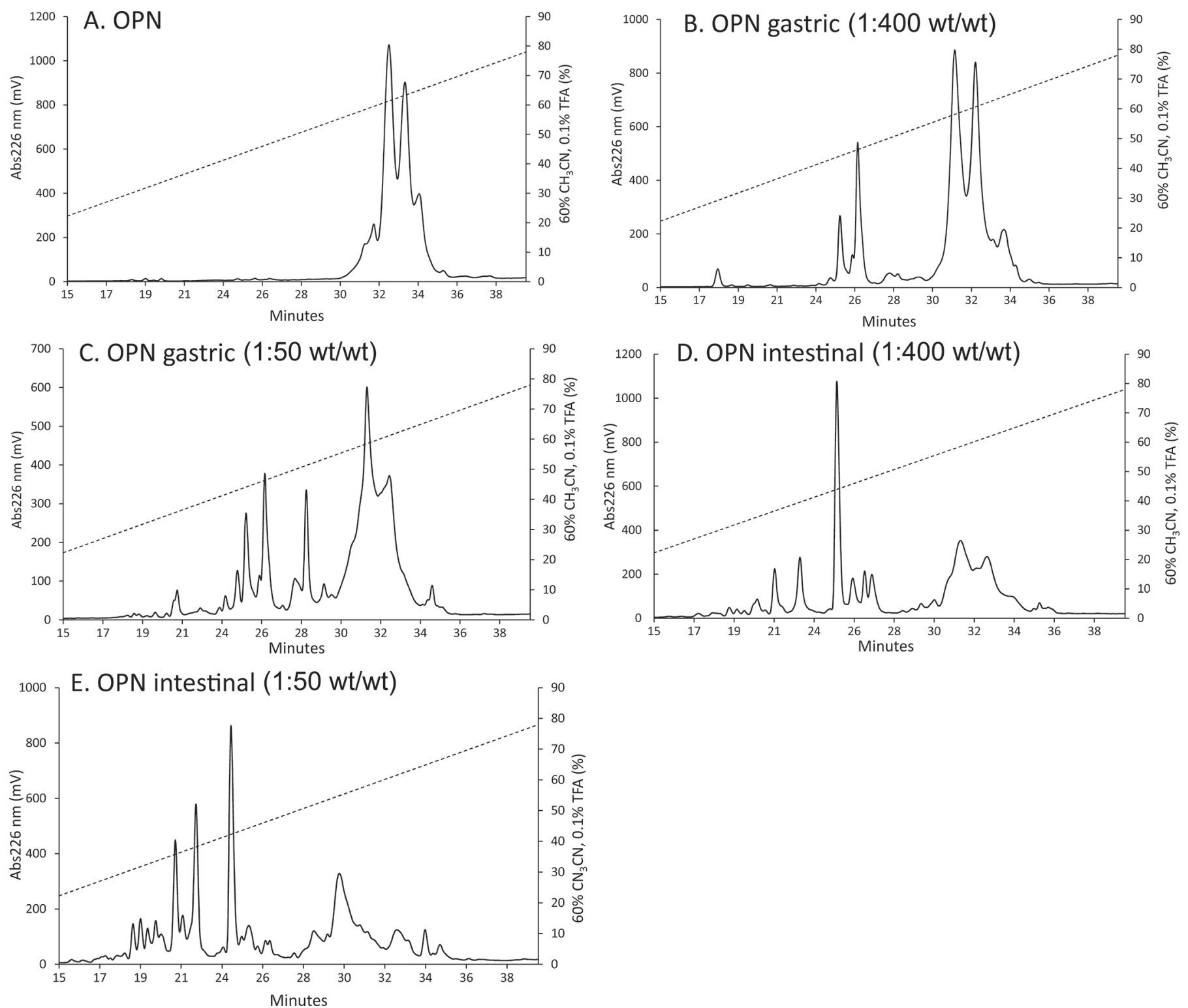

Figure 1. Simulated gastrointestinal digestion of bovine milk osteopontin (OPN). Reversed-phase HPLC chromatograms of OPN or OPN after simulated gastric digestion with pepsin at $\mathrm{pH} 2.5$, or intestinal digestion with trypsin and chymotrypsin at $\mathrm{pH} 7.0$. All digestions were performed at a 1:400 (wt/wt) or 1:50 (wt/wt) enzyme-to-substrate ratio for $60 \mathrm{~min}$ at $37^{\circ} \mathrm{C}$. The peptides and fragments were separated by reversed-phase HPLC and eluted with a gradient of $60 \%$ acetonitrile in $0.1 \%$ trifluoroacetic acid (TFA; dashed line). The peptides were detected in the effluent by measuring the absorbance (Abs) at $226 \mathrm{~nm}$ (solid line). 
tention time to the uncleaved OPN was considerably reduced. As expected, we observed more peptides and fragments eluting earlier than the undigested protein (Figure $1 \mathrm{D}-\mathrm{E}$ ). Based on the elution profile, some large OPN fragments resisted gastric - and to some degree, pancreatic - digestion (Figure 1). These larger fragments were purified by gel filtration from digests of both native and deglycosylated OPN (data not shown).

We analyzed the fragments by Western blotting using the monoclonal MAB222p antibody, which recognizes the integrin-binding sequences of OPN (Figure 2A). The MAB222p antibody recognized OPN species migrating, corresponding to masses of approximately 50 and 25 to $30 \mathrm{kDa}$ in SDS-PAGE of the sample not incubated with enzymes (Figure 2B, lane 2). These bands represented the full-length protein and N-terminal OPN fragments naturally present in bovine milk (Christensen and $\mathrm{S} \varnothing-$ rensen, 2014). Fragments migrating at 25 to $30 \mathrm{kDa}$ also reacted with the MAB222p antibody in both pepsin digests of OPN (Figure 2B, lane 3-4). After diges-
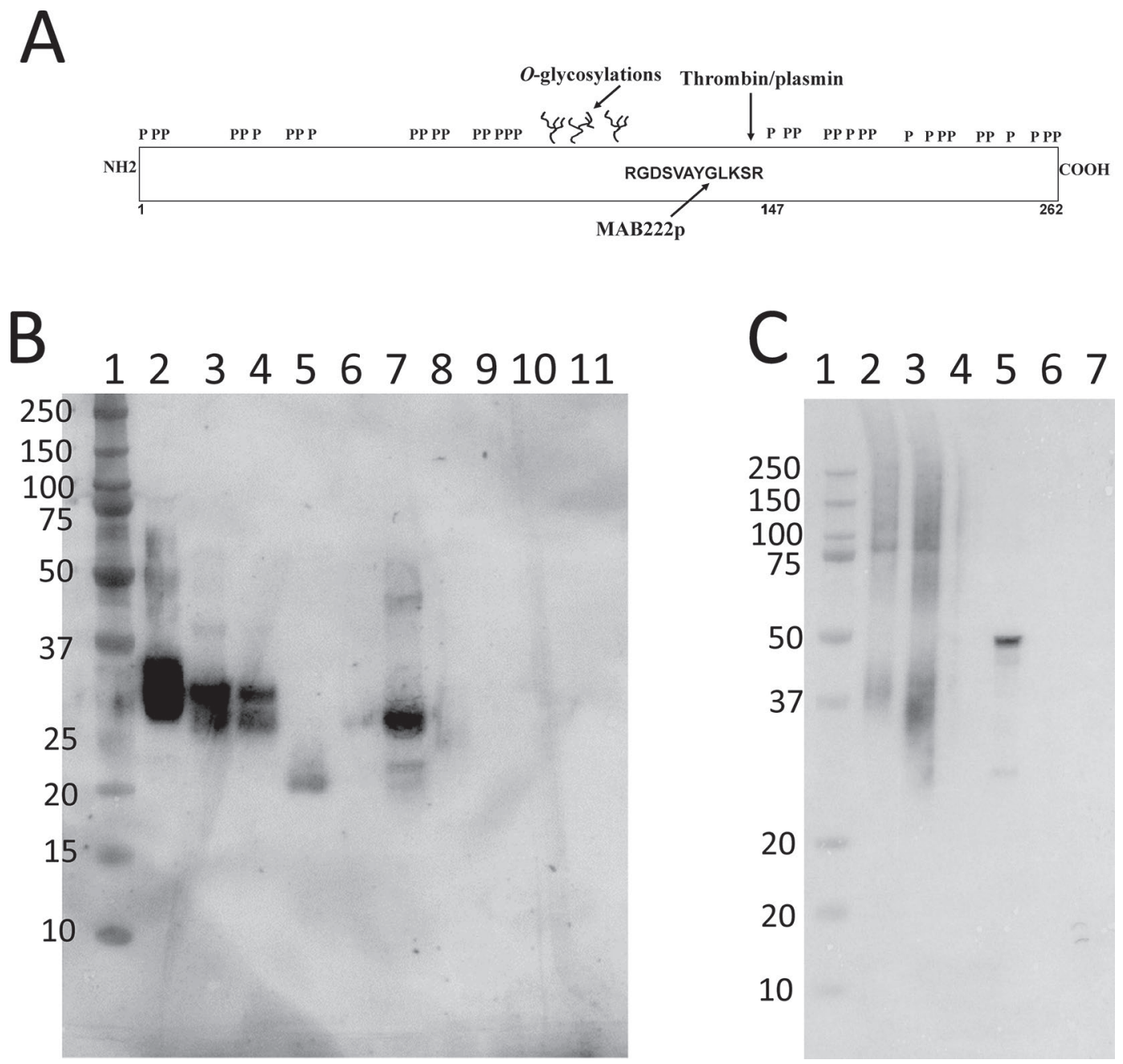

Figure 2. Western blotting of osteopontin (OPN) after simulated gastrointestinal digestion. (A) Schematic representation of bovine OPN. The localization of phosphorylations (P) and O-glycosylations is based on the posttranslational modification pattern of bovine milk OPN (Sørensen et al., 1995). The integrin-binding RGD and SVAYGLK motifs in OPN are shown. The localization of the epitope of the monoclonal anti-OPN antibody MAB222p is also indicated. (B) Western blotting of digested native (lanes 2-6) and deglycosylated OPN (lane 7-11) from bovine milk using the monoclonal antibody MAB222p. Lane 1, molecular weight standards; lane 2, OPN; lanes 3-4, OPN digested with pepsin at a 1:400 (wt/wt) (lane 3) or a 1:50 (wt/wt) enzyme-to-substrate ratio (lane 4); lanes 5-6, OPN further digested with trypsin and chymotrypsin at a 1:400 (wt/wt) (lane 5) or a 1:50 (wt/wt) enzyme-to-substrate ratio (lane 6); lane 7, deglycosylated OPN; lanes 8-9, deglycosylated OPN digested with pepsin at a 1:400 (wt/wt) (lane 8) or a 1:50 (wt/wt) enzyme-to-substrate ratio (lane 9); lanes 10-11, deglycosylated OPN further digested with trypsin and chymotrypsin at a 1:400 (wt/wt) (lane 10) or a 1:50 (wt/wt) enzyme-to-substrate ratio (lane 11). (C) Western blotting of digested human milk OPN (lanes 2-4) and recombinant human OPN (lanes 5-7) using the monoclonal antibody MAB222p. The digests were performed using an enzyme-to-substrate of 1:50 (wt/wt). Lane 1, molecular weight standards; lanes 2 and 5 , undigested OPN from breast milk or recombinant human OPN; lanes 3 and 6, pepsin-digested OPN; lanes 4 and 7, human OPN further digested with trypsin and chymotrypsin. 


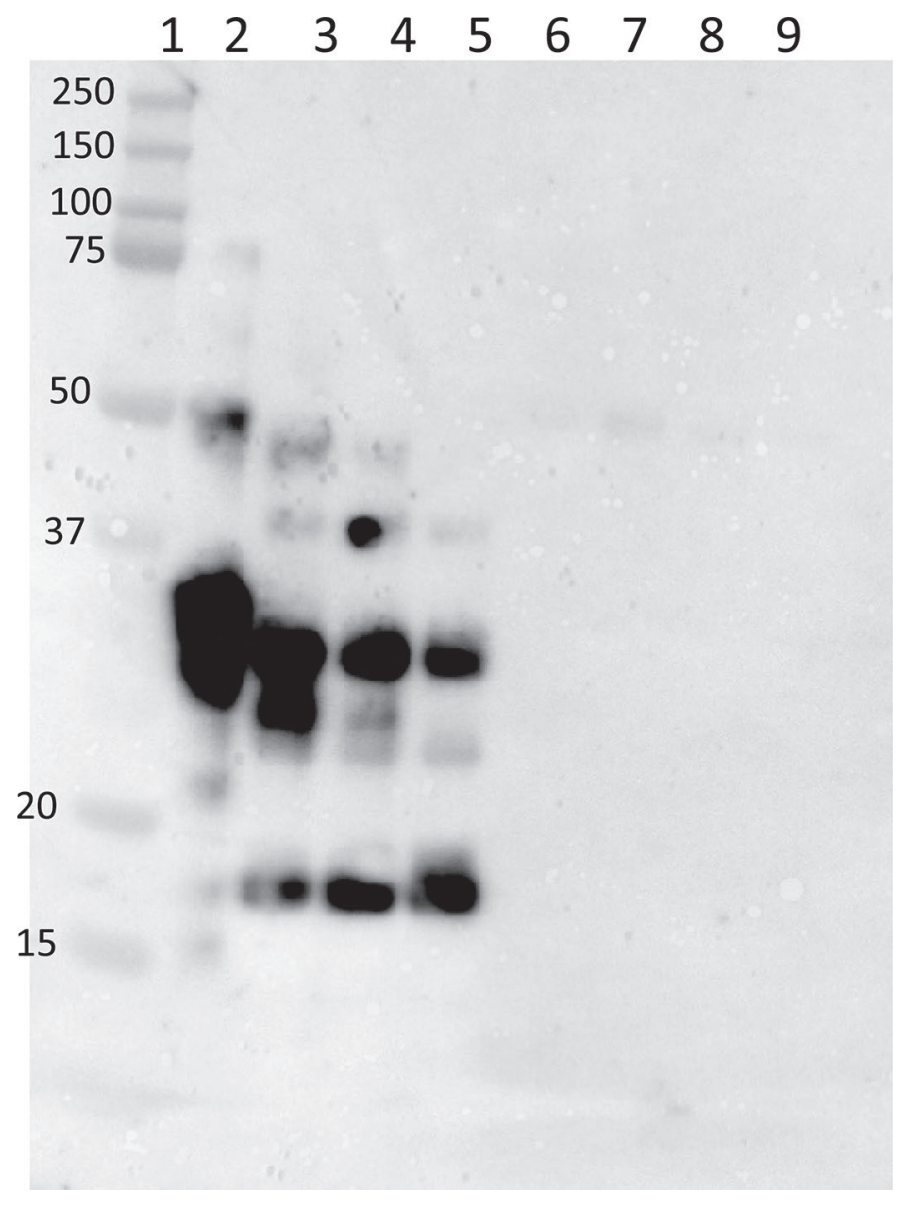

Figure 3. Western blotting using the monoclonal antibody MAB222p of bovine milk osteopontin (OPN) after digestion in a combined gastric and intestinal in vitro model simulating adult gastrointestinal digestion. Bovine milk OPN (5 mg) was mixed with skim milk proteins $(50 \mathrm{mg})$ before they were dissolved in gastric medium. Lane 1, molecular weight standards; lane 2, undigested OPN; lanes $3-5$, OPN incubated in the gastric medium for $5 \mathrm{~min}$ (lane 3), $15 \mathrm{~min}$ (lane 4), and $30 \mathrm{~min}$ (lane 5); lanes 6-9, OPN incubated in intestinal medium for $5 \mathrm{~min}$ (lane 6), $15 \mathrm{~min}$ (lane 7), $30 \mathrm{~min}$ (lane 8), and 60 min (lane 9). tion with the intestinal proteases, we detected a band migrating at approximately $20 \mathrm{kDa}$ with the MAB222p antibody in the digest using 1:400 (wt/wt) enzymeto-substrate ratios, but no bands in the digests using the 1:50 (wt/wt) enzyme-to-substrate ratio (Figure 2 , lane 5-6). In contrast, only uncleaved deglycosylated forms were detected by the MAB222p antibody (Figure 2C, lane 7-11), indicating that the glycosylations protected OPN against proteolytic cleavage in the integrin-binding region. Furthermore, we compared gastrointestinal digestion of human milk OPN with the digestion of recombinant (nonmodified) human OPN (Figure 2C). The MAB222p antibody detected 2 blurry bands migrating at approximately 75 and $37 \mathrm{kDa}$ in the undigested human milk samples (Figure 2C, lane 2). These bands represented the full-length protein and Nterminal fragments of OPN, respectively (Christensen et al., 2010). We also observed these bands after gastric, but not intestinal, digestion (Figure 2C, lane 3-4). In contrast, only undigested recombinant OPN was detected by the MAB222p antibody, indicating that the non-glycosylated form was cleaved in the integrinbinding domain by pepsin (Figure 2C, lane 5-7).

We also investigated the digestion of OPN in a combined gastric and intestinal in vitro digestion model simulating conditions of the adult human gastrointestinal tract. In this digestion model, an OPN fragment migrating at 25 to $30 \mathrm{kDa}$ was observed to resist the gastric digestion (Figure 3, lanes 3-5), but after exposure to in vitro intestinal conditions, no OPN species containing the epitope recognized by the MAB222p antibody could be detected (Figure 3, lanes 6-9).

The present data show that an OPN fragment containing the integrin-binding motifs resists simulated gastric digestion only if it is glycosylated (Figure 2B-C). The bovine OPN fragment generated by pepsin digestion was further digested with trypsin or Asp-N, followed by

Table 2. Characterization of bovine milk osteopontin fragments generated by pepsin ${ }^{1}$

\begin{tabular}{|c|c|c|c|c|}
\hline Treatment & Peptide & $\begin{array}{l}\text { Measured } \\
\quad(\mathrm{Da})\end{array}$ & $\begin{array}{l}\text { Expected } \\
\text { (Da) }\end{array}$ & $\begin{array}{l}\text { Mass difference } \\
\text { (Da) }\end{array}$ \\
\hline \multirow{2}{*}{ Trypsin } & ${ }^{27} \mathrm{WLKPDPSQK}^{35}$ & $1,098.65$ & $1,098.59$ & -0.06 \\
\hline & ${ }^{36}$ QTFLAPQNSVSSEETDDNK ${ }^{54}$ & $2,110.13$ & $2,109.95$ & -0.18 \\
\hline \multirow[t]{3}{*}{ Asp-N } & ${ }^{27}$ WLKPDPSQKQTFLAPQNSVSSEET ${ }^{50}$ & $2,717.43 / 2,797.44$ & $2,717.33$ & $-0.1 /-80.11(1 \mathrm{P})$ \\
\hline & ${ }^{52} \mathrm{DNKQNTLPSKSNESPEQTD}{ }^{70}$ & $2,131.93 / 2,211.85$ & $2,131.97$ & $0.04 /-79.88(1 \mathrm{P})$ \\
\hline & ${ }^{70}$ DDLDDDDDNSQDVNSNDSDDAETTD ${ }^{94}$ & $2,904.61 / 2,984.85$ & $2,744.94$ & $-159.67(2 \mathrm{P}) /-239.91(3 \mathrm{P})$ \\
\hline
\end{tabular}

${ }^{1}$ The fragment of bovine milk osteopontin generated by pepsin at an enzyme-to-substrate ratio of 1:50 (wt/wt) purified by gel filtration was further sub-digested with trypsin or Asp-N, followed by reversed-phase HPLC separation of the resulting peptides that were characterized by MS. Monoisotopic molecular masses $\left(\mathrm{MH}^{+}\right)$were measured by MALDI-MS. The expected masses $\left(\mathrm{MH}^{+}\right)$were calculated using GPMAW software (Lighthouse Data, Odense, Denmark). Differences (Da) between measured and expected masses are listed. Mass difference corresponding to a phosphorylation is denoted $(\mathrm{P})$. 
Table 3. Pepsin cleavage sites in deglycosylated bovine milk osteopontin ${ }^{1}$

\begin{tabular}{lccc}
\hline \multirow{2}{*}{ Peptide } & $\begin{array}{c}\text { Measured } \\
(\mathrm{Da})\end{array}$ & $\begin{array}{c}\text { Expected } \\
(\mathrm{Da})\end{array}$ & $\begin{array}{c}\text { Mass difference } \\
(\mathrm{Da})\end{array}$ \\
122 VFTPFIPTESANDGRGDSVA $^{141}$ & $2,080.09$ & $2,079.99$ & -0.10 \\
${ }^{122}$ VFTPFIPTESANDGRGDSVAY & $2,243.05$ & -0.10 \\
${ }^{122}$ VFTPFIPTESANDGRGDSVAYGLKSRSKKF & $2,243.15$ & $3,274.68$ & -0.07 \\
\hline
\end{tabular}

${ }^{1}$ The fragments and peptides of deglycosylated bovine milk osteopontin generated by pepsin at an enzyme-to-substrate ratio of 1:400 (wt/ wt) were separated by reversed-phase HPLC and subsequently characterized by MS. Monoisotopic molecular masses $\left(\mathrm{MH}^{+}\right)$were measured by MALDI-MS. The expected masses $\left(\mathrm{MH}^{+}\right)$were calculated using GPMAW software (Lighthouse Data, Odense, Denmark). Differences (Da) between measured and expected masses are listed.

MALDI-MS characterization. The analyses showed that pepsin cleavage generates the OPN fragment $\operatorname{Trp}^{27}$ Phe $^{151}$ (Table 2). As expected, this fragment contained both the RGD and SVAYGLK integrin-binding motifs. Edman sequencing verified that the $\mathrm{N}$-terminal sequence of the fragment started at Trp ${ }^{27}$. In Asp- $\mathrm{N}$ and trypsin sub-digests of pepsin-cleaved deglycosylated OPN, the ${ }^{27}$ WLKPDPSQK ${ }^{35}$ peptide - but importantly not the ${ }^{138}$ DSVAYGLKSRSKKF ${ }^{151}$ peptide - was identified (data not shown). Instead, pepsin was shown to cleave deglycosylated OPN at the $\mathrm{Ala}^{121}-\mathrm{Val}^{122}$ bond, because several peptides starting at $\mathrm{Val}^{121}$ were identified in the peptic digests of the deglycosylated protein (Table 3 ). These peptides were not detected in the corresponding pepsin digest of native glycosylated OPN. The identified pepsin cleavage sites in glycosylated and deglycosylated OPN are summarized in Figure 4. In Asp-N and tryptic sub-digests of native and deglycosylated OPN digested by both gastric and pancreatic proteases, the peptides ${ }^{27}$ WLKPDPSQK $^{35}$ and ${ }^{138}$ DSVAYGLKSRSKKF ${ }^{151}$ were not detected (data not shown).

To test whether digested OPN could interact with cells, we performed an adhesion assay with MDA-
MB-435 cells. Adhesion to native and deglycosylated OPN was robust and comparable. Similarly, the peptic fragments from glycosylated OPN, but not deglycosylated OPN, mediated strong cell adhesion (Figure 5A). Of the OPN forms incubated with trypsin and chymotrypsin, only glycosylated OPN at the 1:400 enzymeto-substrate ratio interacted with the cells. In all cases, the addition of an RGD peptide abolished the adhesion, whereas an RAD peptide was ineffective in blocking adhesion (Figure 5B).

\section{DISCUSSION}

Bovine milk OPN contains $3 O$-glycosylated threonine residues in a threonine-proline-rich region located just before the RGD motif in the OPN sequence (Sørensen et al., 1995; see Figures 1 and 4). These threonines are well conserved among mammalian OPN sequences, and they are also glycosylated in OPN from human milk, urine, and bone (Christensen et al., 2005, 2007, 2008). The functional role of OPN glycosylation in milk is not clear, but the location close to the integrin-binding motifs could suggest a protective role against proteoly-

\section{P P PP
LPVKPTSSGSSEEKQLNNKYPDAVATWLKPDPSQKQTFLAPQNSVSSEETDDNKQNTL $\quad \mathbf{5 8}$}

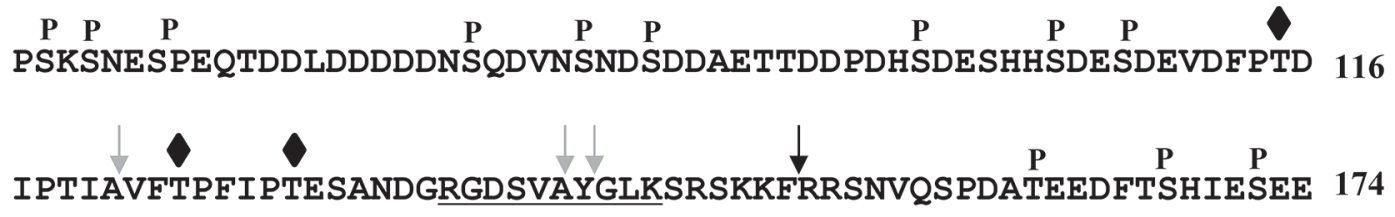

$\stackrel{P}{\text { MHDAPKKTSQLTDHSKETNSSELSKELTPKAKDKNKHSNLIESQENSKLSOEFHSLED }} \underset{\mathbf{P}}{\mathbf{P}} \stackrel{\text { P }}{\mathbf{P}}$

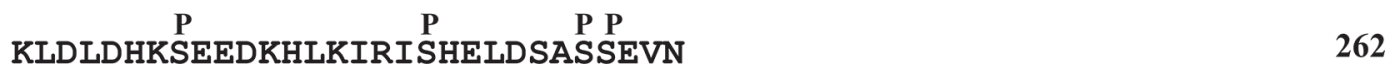

Figure 4. Pepsin cleavage sites in osteopontin (OPN). The cleavages in native (black) and deglycosylated OPN (black and gray) are indicated with arrows. The RGD and SVAYGLK motifs are underlined. Phosphorylations (P) and $O$-glycosylations (diamonds) indicate modified residues identified in bovine milk OPN (Sørensen et al., 1995). 
sis by endogenous milk proteases or digestive enzymes. Such a protective role was shown in this study, where the glycosylated OPN fragment $\operatorname{Trp}^{27}-\mathrm{Phe}^{151}$ containing the RGD and the SVAYGLK integrin-binding sequences resisted pepsin cleavage (Figures 2 and 3). In contrast, we did observe pepsin cleavage at $\mathrm{Ala}^{121}-\mathrm{Val}^{122}$ in deglycosylated bovine OPN. This cleavage site is located between 2 threonines that are normally glycosylated in bovine milk OPN (Figure 4). Similarly, the integrinbinding motifs in human milk OPN also resisted gastric digestion, whereas the recombinant (nonmodified) human OPN did not (Figure 2C).

Osteopontin is well known for its ability to interact with cells through the well conserved integrinbinding RGD sequence. Previously, MDA-MB-435 cells have been used as a model cell line for studying RGD-mediated cell adhesion by OPN (Christensen et al., 2007; Malmström et al., 2010). The glycosylated $\operatorname{Trp}^{27}-\mathrm{Phe}^{151}$ fragment retained the ability to mediate RGD-dependent cell adhesion of the MDA-MB-435 cells, whereas pepsin-cleaved deglycosylated OPN did not support cell binding (Figure 5). A protective effect of OPN glycosylation against gastrointestinal digestion has previously been indicated, because administration of exogenous bovine milk OPN, but not nonmodified recombinant OPN, in drinking water attenuated several disease variables in a mouse model of colitis (da Silva et al., 2009).

The majority of OPN is presumably digested to small peptides and amino acids during passage through the stomach and duodenum, but the present study showed that the fragment $\operatorname{Trp}^{27}-\mathrm{Phe}^{151}$ containing both OPN integrin-binding motifs resisted incubation with pepsin at $\mathrm{pH} 2.5$ for $1 \mathrm{~h}$ at $37^{\circ} \mathrm{C}$ (Figure $2 \mathrm{~B}$ ). Several bulky hydrophobic amino acids and leucine residues that usually represent good cleavage sites for pepsin are present in the Trp ${ }^{27}-\mathrm{Phe}^{151}$ fragment (Ahn et al., 2013). However, these sites are most likely protected by nearby posttranslational modifications such as phosphorylations, and as shown in this study, glycosylated OPN has been shown to resist proteolysis with neonatal gastric aspirates at $\mathrm{pH} 3.0$ for $1 \mathrm{~h}$ at $37^{\circ} \mathrm{C}$ (Chatterton et al., 2004). As well, OPN has been shown to resist digestion in vivo in mice fed OPN by gavage or solubilized in chocolate milk (da Silva et al., 2009; Rittling et al., 2014). Bovine OPN was also detected in the plasma of human infants fed formula supplemented with bovine milk OPN (Jiang and Lönnerdal, 2019). In these studies, OPN was detected by ELISA or immunohistochemistry, and it is not clear which forms or fragments of OPN were present after digestion. Collectively, more studies indicate that part of the ingested OPN reaches the duodenum and is absorbed in a form that can bind integrins, so that it may be able to engage in signaling events in the intestine or even in the circulation.

In vivo human digestion of proteins is a complex process depending on several factors, such as the activity of digestive enzymes, the acid conditions, the transit in the stomach and intestines, and the food matrix. In this study, we observed the OPN fragment Trp ${ }^{27}-\mathrm{Phe}^{151}$ after incubation of OPN with pepsin at enzyme-to-substrate ratios of 1:50 and 1:400 (wt/wt). Furthermore, in a di-
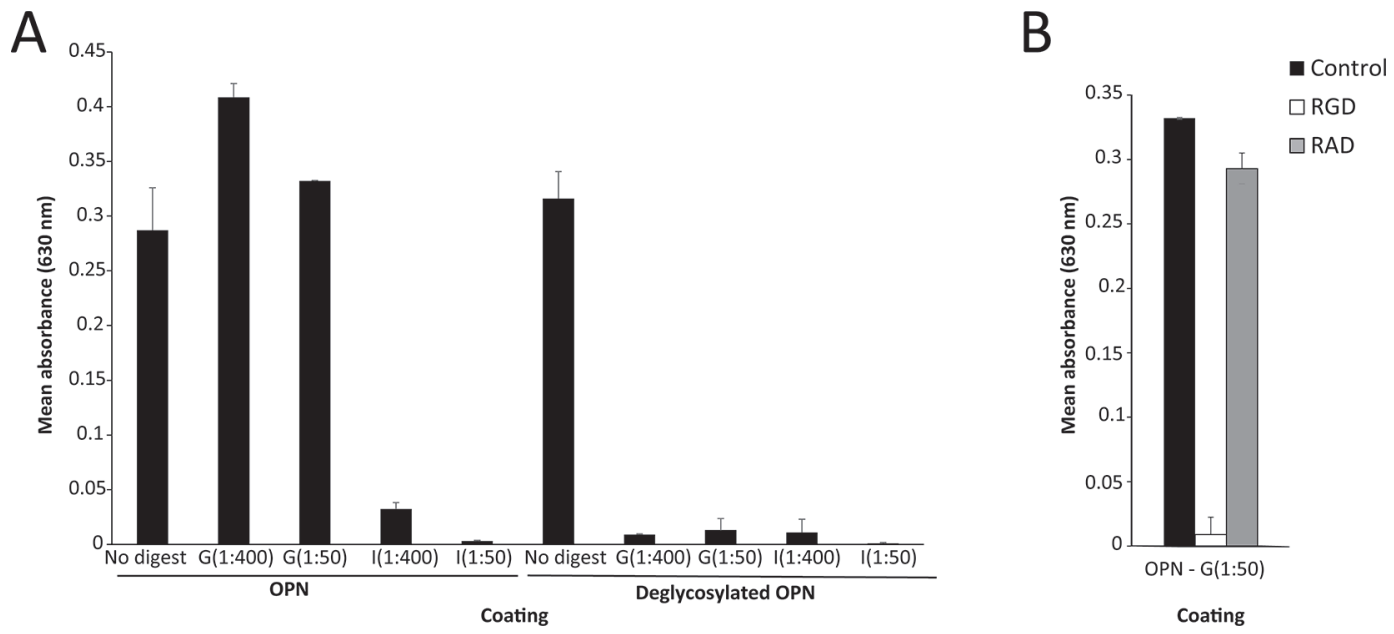

Figure 5. Cell adhesion of MDA-MB-435 cells to digests of bovine milk osteopontin (OPN). (A) Wells of microtiter plates coated with native or deglycosylated bovine milk OPN with or without gastric digestion with pepsin at a 1:400 (wt/wt) [G(1:400)] or 1:50 (wt/wt) [G(1:50)] enzyme-to-substrate ratio, and intestinal digestion with trypsin and chymotrypsin at a 1:400 (wt/wt) [I(1:400)] or 1:50 (wt/wt) [I(1:50)] enzyme-to-substrate ratio. (B) Wells of microtiter plates coated with native milk OPN G(1:50). Cells were preincubated with or without 100 $\mu M$ GRGDNP (RGD) or GRADSP (RAD) peptide; 1\% BSA was used as a negative control and subtracted from all values. For all experiments, data are expressed as mean $\pm \mathrm{SD}(\mathrm{n}=3)$. 
gestion model simulating adult human gastrointestinal conditions, we observed the presence of the bioactive OPN fragment. This established model consecutively simulated gastric and intestinal digestion in terms of volume of gastrointestinal fluids, $\mathrm{pH}$, enzyme activity, and bile salt and phospholipid concentrations, based on a literature review (Thomas et al., 2014). Therefore, it is likely that the formation and existence of a large OPN fragment containing the important integrinbinding motifs in OPN survives passage through the stomach and reaches the intestines in vivo, especially in infants with lower gastric pepsin concentration, higher $\mathrm{pH}$, and continuous exposure to milk in the gastrointestinal tract (Dallas et al., 2012).

In this study, we showed that the OPN fragment $\operatorname{Trp}^{27}$-Phe ${ }^{151}$ containing integrin-binding motifs resisted simulated gastric digestion. This resistance against digestion was shown to depend on the glycosylation of OPN, because deglycosylated OPN was cleaved in the integrin-binding region. The presence of biologically active OPN fragments after gastric digestion could explain how OPN, via binding to integrins in the intestine, can deliver signals responsible for the physiological effects of orally ingested OPN reported in animal studies and human clinical interventions.

\section{ACKNOWLEDGMENTS}

The project received funding from the Danish Dairy Research Foundation (Aarhus N, Denmark) and Arla Foods Ingredients Group P/S (Viby J, Denmark). The human MDA-MB-435 cell line was a kind gift from Professor David T. Denhardt (Rutgers University, NJ).

\section{REFERENCES}

Ahn, J., M.-J. Cao, Y. Q. Yu, and J. R. Engen. 2013. Accessing the reproducibility and specificity of pepsin and other aspartic proteases. Biochim. Biophys. Acta 1834:1222-1229. https://doi.org/10 .1016/j.bbapap.2012.10.003.

Ashkar, S., G. F. Weber, V. Panoutsakopoulou, M. E. Sanchirico, M. Jansson, S. Zawaideh, S. R. Rittling, D. T. Denhardt, M. J. Glimcher, and H. Cantor. 2000. Eta-1 (osteopontin): An early component of type-1 (cell-mediated) immunity. Science 287:860-864.

Bruun, S., L. N. Jacobsen, X. Ze, S. Husby, H. M. Ueno, K. Nojiri, S. Kobayashi, J. Kwon, X. Liu, S. Yan, J. Yang, G. Zachariassen, L. Chen, W. Zhou, B. Christensen, and E. S. Sørensen. 2018. Osteopontin levels in human milk vary across countries and within lactation period: Data from a multicenter study. J. Pediatr. Gastroenterol. Nutr. https://doi.org/10.1097/MPG.0000000000002004.

Chatterton, D. E. W., J. T. Rasmussen, C. W. Heegaard, E. S. S $\varnothing-$ rensen, and T. E. Petersen. 2004. In vitro digestion of novel milk protein ingredients for use in infant formulas: Research on biological functions. Trends Food Sci. Technol. 15:373-383. https://doi .org/10.1016/j.tifs.2003.12.004.

Christensen, B., C. C. Kazanecki, T. E. Petersen, S. R. Rittling, D. T. Denhardt, and E. S. Sørensen. 2007. Cell type-specific post-translational modifications of mouse osteopontin are associated with different adhesive properties. J. Biol. Chem. 282:19463-19472. https://doi.org/10.1074/jbc.M703055200.

Christensen, B., E. Kläning, M. S. Nielsen, M. H. Andersen, and E. S. Sørensen. 2012. C-terminal modification of osteopontin inhibits interaction with the $\alpha \mathrm{V} \beta 3$-integrin. J. Biol. Chem. 287:3788-3797. https://doi.org/10.1074/jbc.M111.277996.

Christensen, B., M. S. Nielsen, K. F. Haselmann, T. E. Petersen, and E. S. Sørensen. 2005. Post-translationally modified residues of native human osteopontin are located in clusters: Identification of 36 phosphorylation and five O-glycosylation sites and their biological implications. Biochem. J. 390:285-292. https://doi.org/10.1042/ BJ20050341

Christensen, B., T. E. Petersen, and E. S. Sørensen. 2008. Post-translational modification and proteolytic processing of urinary osteopontin. Biochem. J. 411:53-61. https://doi.org/10.1042/BJ20071021.

Christensen, B., L. Schack, E. Kläning, and E. S. Sørensen. 2010. Osteopontin is cleaved at multiple sites close to its integrin-binding motifs in milk and is a novel substrate for plasmin and cathepsin D. J. Biol. Chem. 285:7929-7937. https://doi.org/10.1074/jbc .M109.075010.

Christensen, B., and E. S. Sørensen. 2014. Osteopontin is highly susceptible to cleavage in bovine milk and the proteolytic fragments bind the $\alpha \mathrm{V}_{3}$-integrin receptor. J. Dairy Sci. 97:136-146. https:/ /doi.org/10.3168/jds.2013-7223.

Christensen, B., E. D. Zachariae, C. Scavenius, S. Kløverpris, C. Oxvig, S. V. Petersen, J. J. Enghild, and E. S. Sørensen. 2016. Transglutaminase 2-catalyzed intramolecular cross-linking of osteopontin. Biochemistry 55:294-303. https://doi.org/10.1021/acs .biochem.5b01153.

da Silva, A. P. B., R. P. Ellen, E. S. Sørensen, H. A. Goldberg, R. Zohar, and J. Sodek. 2009. Osteopontin attenuation of dextran sulfate sodium-induced colitis in mice. Lab. Invest. 89:1169-1181. https://doi.org/10.1038/labinvest.2009.80.

Dallas, D. C., M. A. Underwood, A. M. Zivkovic, and J. B. German. 2012. Digestion of protein in premature and term infants. J. Nutr Disord. Ther. 2:112. https://doi.org/10.4172/2161-0509.1000112.

Donovan, S. M., M. H. Monaco, J. Drnevich, A. S. Kvistgaard, O. Hernell, and B. Lönnerdal. 2014. Bovine osteopontin modifies the intestinal transcriptome of formula-fed infant rhesus monkeys to be more similar to those that were breastfed. J. Nutr. 144:1910-1919. https://doi.org/10.3945/jn.114.197558.

Holt, C., S. Lenton, T. Nylander, E. S. Sørensen, and S. C. M. Teixeira. 2014. Mineralisation of soft and hard tissues and the stability of biofluids. J. Struct. Biol. 185:383-396. https://doi.org/10.1016/ j.jsb.2013.11.009.

Jiang, R., and B. Lönnerdal. 2019. Osteopontin in human milk and infant formula affects infant plasma osteopontin concentrations. Pediatr. Res. 85:502-505. https://doi.org/10.1038/s41390-018 -0271-x.

Kahles, F., H. M. Findeisen, and D. Bruemmer. 2014. Osteopontin: A novel regulator at the cross roads of inflammation, obesity and diabetes. Mol. Metab. 3:384-393. https://doi.org/10.1016/j.molmet .2014.03.004.

Kolbach, A. M. O. Afzal, B. Halligan, E. Sorokina, J. G. Kleinman, and J. A. Wesson. 2012. Relative deficiency of acidic isoforms of osteopontin from stone former urine. Urol. Res. 40:447-454. https: //doi.org/10.1007/s00240-012-0459-1.

Lok, Z. S. Y., and A. N. Lyle. 2019. Osteopontin in vascular disease. Arterioscler. Thromb. Vasc. Biol. 39:613-622. https://doi.org/10 .1161/ATVBAHA.118.311577.

Lönnerdal, B., A. S. Kvistgaard, J. M. Peerson, S. M. Donovan, and Y. Peng. 2016. Growth, nutrition, and cytokine response of breastfed infants and infants fed formula with added bovine osteopontin. J. Pediatr. Gastroenterol. Nutr. 62:650-657. https://doi.org/10 .1097/MPG.0000000000001005.

Malmström, J., B. Christensen, H. P. Jakobsen, J. Lovmand, R. Foldbjerg, E. S. Sørensen, and D. S. Sutherland. 2010. Large area protein patterning reveals nanoscale control of focal adhesion development. Nano Lett. 10:686-694. https://doi.org/10.1021/nl903875r. 
Park, D., C.-W. Park, Y. Choi, J. Lin, D.-H. Seo, H.-S. Kim, S. Y. Lee, and I.-C. Kang. 2016. A novel small-molecule PPI inhibitor targeting integrin $\alpha v \beta 3$-osteopontin interface blocks bone resorption in vitro and prevents bone loss in mice. Biomaterials 98:131-142. https://doi.org/10.1016/j.biomaterials.2016.05.007.

Rittling, S. R., P. L. Wejse, K. Yagiz, G. A. Warot, and T. Hui. 2014 Suppression of tumour growth by orally administered osteopontin is accompanied by alterations in tumour blood vessels. Br. J. Cancer 110:1269-1277. https://doi.org/10.1038/bjc.2014.10.

Schack, L., A. Lange, J. Kelsen, J. Agnholt, B. Christensen, T. E. Petersen, and E. S. Sørensen. 2009. Considerable variation in the concentration of osteopontin in human milk, bovine milk, and infant formulas. J. Dairy Sci. 92:5378-5385. https://doi.org/10 $.3168 /$ jds.2009-2360.

Sørensen, E. S., P. Højrup, and T. E. Petersen. 1995. Posttranslational modifications of bovine osteopontin: Identification of twentyeight phosphorylation and three O-glycosylation sites. Protein Sci. 4:2040-2049. https://doi.org/10.1002/pro.5560041009.

Thomas, N., K. Richter, T. B. Pedersen, R. Holm, A. Müllertz, and T. Rades. 2014. In vitro lipolysis data does not adequately predict the in vivo performance of lipid-based drug delivery systems containing fenofibrate. AAPS J. 16:539-549. https://doi.org/10.1208/ s12248-014-9589-4.

West, C. E., A. S. Kvistgaard, J. M. Peerson, S. M. Donovan, Y.M. Peng, and B. Lönnerdal. 2017. Effects of osteopontin-enriched formula on lymphocyte subsets in the first 6 months of life: A randomized controlled trial. Pediatr. Res. 82:63-71. https://doi .org/10.1038/pr.2017.77.

Yokosaki, Y., K. Tanaka, F. Higashikawa, K. Yamashita, and A. Eboshida. 2005. Distinct structural requirements for binding of the integrins alphavbeta6, alphavbeta3, alphavbeta5, alpha5beta1 and alpha9beta1 to osteopontin. Matrix Biol. 24:418-427. https://doi .org/10.1016/j.matbio.2005.05.005.

\section{ORCIDS}

S. V. Petersen (๑ https://orcid.org/0000-0002-9338-911X

E. S. Sørensen ๑ https://orcid.org/0000-0002-7050-3354 